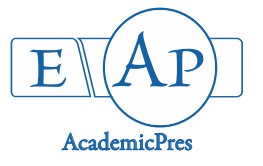

Ravi Shankar S and Dayanandan P (2020)

Notulae Scientia Biologicae 12(4):852-868

DOI: $10.15835 / 12410714$

Research Article

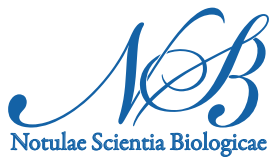

\title{
Structure and histochemistry of sorghum caryopsis in relation to grain-filling
}

\author{
S. RAVI SHANKAR*, P. DAYANANDAN \\ Madras Christian College (Autonomous), Department of Botany, Chennai, 600059 , \\ India;botanyravi@gmail.com (*corresponding author);p.dayanandan@gmail.com
}

\begin{abstract}
Anatomical and histochemical studies of ovary and caryopsis of sorghum reveal the importance of the chalazal complex in transporting nutrients from maternal sources to the filial diploid embryo and triploid endosperm. The presence of starch, protein, lipid, $\mathrm{Ca}, \mathrm{K}, \mathrm{Mg}$, and $\mathrm{Fe}$ in various tissues at different stages of development can be revealed by a variety of histochemical techniques. Vascular supply ends at the base of the ovary and transport occurs through vascular parenchyma, pigment strand and nucellar projection where symplastic continuity is broken. Nutrients unloaded into an apoplastic placental sac then enter the endosperm and embryo through the aleurone transfer cells. The later possess characteristic wall ingrowth. The single layer of aleurone surrounding the endosperm may also help in transport during later stages of grain-filling. Grainfilling in $\mathrm{C}_{4}$ sorghum is compared with other $\mathrm{C}_{4}$ and $\mathrm{C}_{3}$ grasses showing the variety of strategies evolved to transport nutrients into filial tissues. Standardization of terminologies to describe the tissues of the crease region will help in further research and communication.
\end{abstract}

Keywords: cereal anatomy; grain-filling; histochemistry; microscopy; sorghum caryopsis

\section{Introduction}

The fruit of sorghum, as those of all cereals, is known as a caryopsis. A mature caryopsis consists of a crushed pericarp and integuments derived from maternal tissues, and two filial structures: a diploid embryo and a triploid endosperm. As an extra-embryonic tissue and a product of an independent event of fertilization the endosperm has evolved to provide nourishment to its sibling embryo during germination (Becraft and Gutierrez-Marcos, 2012). Both the endosperm and the embryo store carbohydrates, proteins, lipids and minerals; hence their importance in human nutrition and growth of civilizations since the domestication of cereals, more than ten thousand years ago. Elucidation of the developmental events that result in a mature caryopsis requires knowledge of the anatomy of tissues and cells, pathways of transport of assimilates, sites of deposition and genetic regulations at these sites.

The earliest description of the structure of sorghum caryopsis was provided by Winston (1903), followed by developmental studies of Sanders (1955), Paulson (1968), Rooney and Clark (1968), Wall and Blessin (1969), Rooney and Sullins (1977), Rooney and Miller (1982), Rooney et al. (1983), Maiti (1993) and Wang et al. (2012). Zeleznak and Varriano-Marston (1982) investigated the ultrastructure of sorghum caryopsis. The role of tissues associated with grain-filling in sorghum was investigated by Quinby (1972) and 
Mannes and McBee (1986). Fluorochromes have been used to localize storage components or trace the pathways of translocation mostly in wheat, maize and rice (Schumacher, 1933; Peterson et al., 1981; Cook and Oparka, 1983; Grignon et al., 1989; Oparka, 1991; Wang et al., 1994; Wang and Fisher, 1994 a, b; Wright and Oparka, 1996; Ebenezer, 1997; Krishnan et al., 2001; Krishnan and Dayanandan, 2003). Here we present observations on the anatomy of sorghum caryopsis, localization of storage components and pathways of transport of nutrients during grain-filling.

\section{Materials and Methods}

\section{Plant material}

Seeds of Sorghum bicolor (L.) Moench used in this investigation were obtained from International Crop Research Institute for Semi-Arid Tropics (ICRISAT), Hyderabad, India. A popular, post-rainy (dry) season grain sorghum cultivar 'M 35-1' (Reddy et al., 2009; Reddy et al., 2012) was used for most of the study (Figure 1a, b). Other cultivars, 'IS-18164', 'IS-23509', 'IS-32265', '296-B' and 'Framida' (Figure 1c) were used for comparative analysis. A steady supply of plants in different stages of caryopsis development was ensured by sowing seeds at regular intervals in field plots in the Botany Department nursery.

\section{Specimen preparation and histochemical staining}

Developing caryopses were removed from the panicles of plants at selected stages beginning from the day of flowering (DAF) till the end of physiological maturity. Both fresh and formalin-acetic acid - alcohol (FAA) fixed material was used for the study. Free-hand sections, paraffin-wax embedded and plastic-embedded sections were used for observation. Procedures outlined in Hawes (1994) were followed for preparing Spurr resin embedded specimens for Transmission Electron Microscope (TEM) studies. A Reichter-Jung Ultracut microtome and glass knives were used for obtaining semi-thin $(1-2 \mu \mathrm{m})$ and ultra-thin $(60 \mathrm{~nm})$ sections. Ultrathin sections were stained using uranyl acetate and lead citrate.

Bright-field dyes, reagents and fluorochromes for staining tissues and localizing various storage components were prepared and used following standard histochemical procedures (Fulcher, 1982; Jensen, 1962; Pearse, 1972, 1980; Harris and Oparka, 1994). Fluorescein and 5(6) carboxyfluorescein have been employed as symplastic tracers for observing the course of movement of assimilates in plants (Grignon et al., 1989; Wright and Oparka, 1996). The dyes were prepared by dissolving $0.1 \mathrm{~g}$ in minimal volume of $0.3 \mathrm{M}$ $\mathrm{KOH}$, diluted with water to obtain $1 \mathrm{mM}$ and adjusted to $6.3 \mathrm{pH}$ with $1 \mathrm{M} \mathrm{HCl}$ (Conn 1977; Clark 1981). These fluorescent dyes were introduced into panicles or spikelet-bearing branchlets by dipping the cut ends for 3-5 hours. The movement of the dye was traced by taking free-hand sections of the crease region near the base of the ovary at various intervals of time and different developmental stages.

\section{Microscopy}

Sections prepared for the above experiments were observed and photographed using a Nikon Microphot-FXA microscope equipped with accessories for bright-field, dark-field, phase-contrast, NomarskiDIC and Fluorescence microscopy. Fluorescence was obtained by excitation in the UV (330-380 nm), violet $(380-425 \mathrm{~nm})$ and blue $(450-490 \mathrm{~nm})$ wavelengths. Stained ultra-thin sections were examined and photographed with a Philips CM10 TEM at the Electron Microscopic Unit of the All India Institute of Medical Sciences, New Delhi. 


\section{Results}

\section{Morphology and development of ovary}

The sorghum caryopsis develops from an ovary of a sessile and fertile spikelet associated with one or more pedicellate spikelets but without functional ovaries. These spikelets are found as racemes on ultimate branches of the rachis. At the time of anthesis, the crassinucellate ovule is the most prominent structure found inside the ovary. During early stages of development, the ovary is still protected by glumes, lemma and palea at later stages the caryopsis is partially exposed from the sterile coverings. The caryopsis reaches full maturity in about 30 days after flowering (DAF). Rapid and programmed changes occur in the structural and chemical components of the maternal ovarian tissues and the filial tissues (embryo, endosperm). In the present study five prominent stages were observed as reference points to understand the anatomical and histochemical changes occurring during grain-filling: anthesis (0 DAF), milky stage (10 DAF), soft dough stage (15 DAF), hard dough stage (25 DAF) and physiological maturity (30 DAF) (Figure 1a).

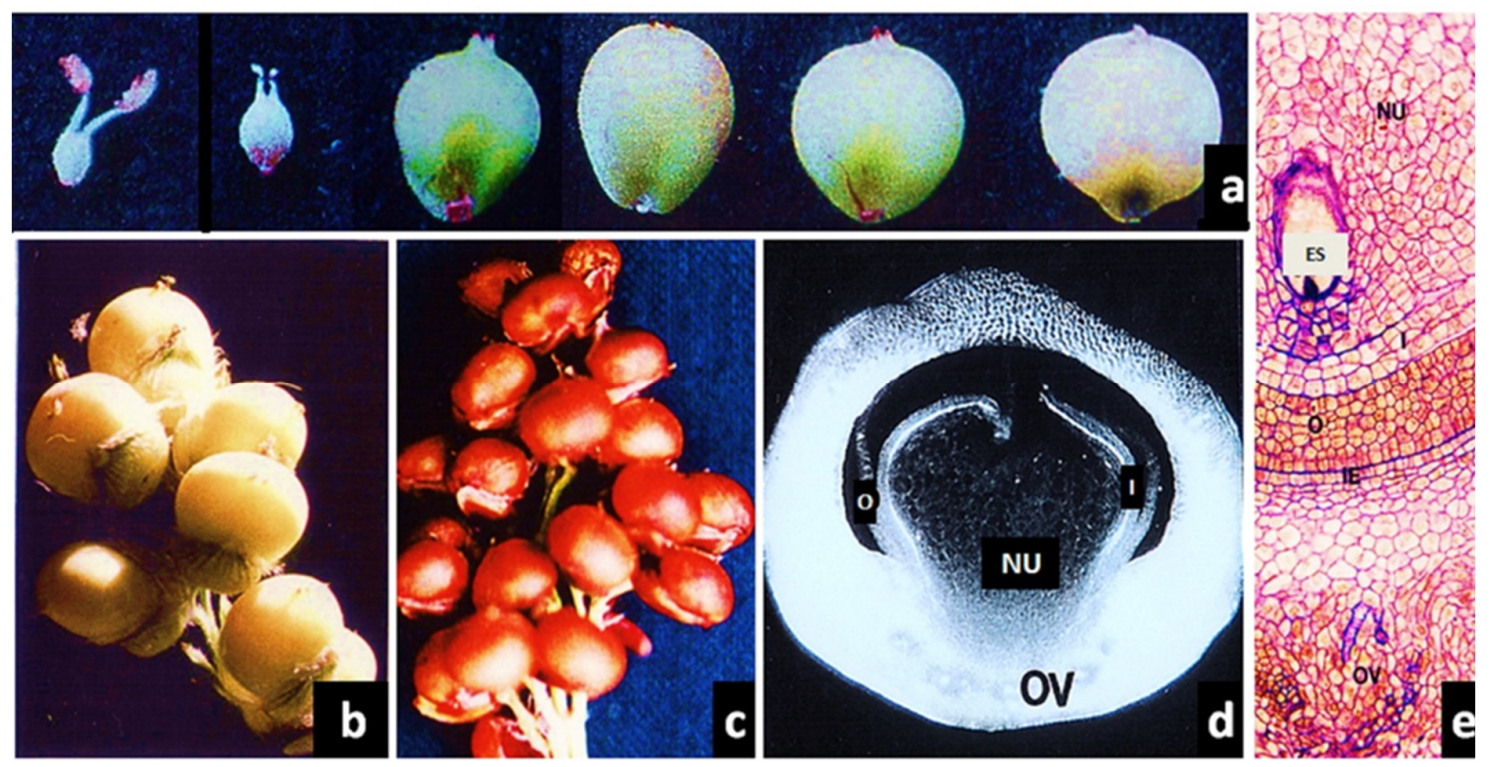

Figure 1. (a) Ovary at anthesis and caryopsis after 1, 10, 15, 25 and 30 DAF

The ovary is about $1 \mathrm{~mm}$ long and the mature grain about $5 \mathrm{~mm}$ long. The small pad of crease tissue region is seen in all four later stages. (b) Mature spikelets with 30-day-old grains. (c) Spikelets of cv. 'Framida' with mature grains. Colour is due to tannin in pericarp and inner integuments. (d) Free hand transverse section (T.S.) of young ovary photographed between crossed polarizers. Pericarp, integuments, vascular traces and nucellus are seen. 60x. (e) Plastic thin section of pre-anthesis ovary stained with Toluidine Blue $\mathrm{O}$ showing cellular details. At this level the outer integument is multilayered. $300 \mathrm{x}$.

(ES, embryo sac; IE, inner integument; NU, nucellus; $\mathrm{O}$, outer integument; $\mathrm{OV}$, ovular vascular trace.)

Other investigators have recognized 8-10 different developmental stages at anthesis the ovary is about 1 $\mathrm{mm}$ long, and it reaches a maximum length of $3-5 \mathrm{~mm}$ and a volume of about $30 \mu \mathrm{l}$ between 10-15 DAF. The dry grain weight of the caryopsis increases from less than $1 \mathrm{mg}$ at anthesis to about 30-35 $\mathrm{mg}$ when the grain (kernel) has reached full maturity. Dry grain weight increases maximally between 15-20 DAF. The import and distribution of storage material into different tissues of the caryopsis parallel the increase in size and weight of the grain over a period of 30 days. In general, mature grains of sorghum consist of about $84 \%$ of endosperm, $10 \%$ of germ and $6 \%$ of bran consisting of remnants of ovary wall and integuments. Vannalli et al. (2008) have determined the percentage of major grains constituents in M 35-1 cultivar as follows: carbohydrate 82.34, protein 12.81 , fat, 1.22 , ash 1.31 and crude fiber 2.32 . About $70 \%$ the carbohydrates in a starch grain is amylopectin; the remainder being amylose. 


\section{Structures associated with grain-filling}

Figures 2 and 3 illustrate the various organs and tissues associated with the developing ovary. These diagrams help understand the changes occurring during development and the structures that play a key role in transport of nutrients into the endosperm and embryo. At anthesis the ovary is slightly elongated and has two prominent styles. The single ovule, surrounded by an ovary wall, consists of a central nucellus surrounded by inner and outer integuments (Figure 1d). The embryo sac is embedded within the nucellus. Prior to fertilization all cells and tissues are maternal in nature and possess diploid nuclei, except the embryo sac, which has haploid egg and associated cells (Figure 1e). Five prominent vascular traces terminating at the base of the ovary constitute the ovular vascular tracers that supply nutrients to the developing caryopsis. Two smaller lateral and transient vascular traces embedded in the ovary wall supply the style and the stigma and they are not involved in nutrient transport into the endosperm during grain-filling. One of these traces is shown in the longitudinal sectional view in Figure 2.

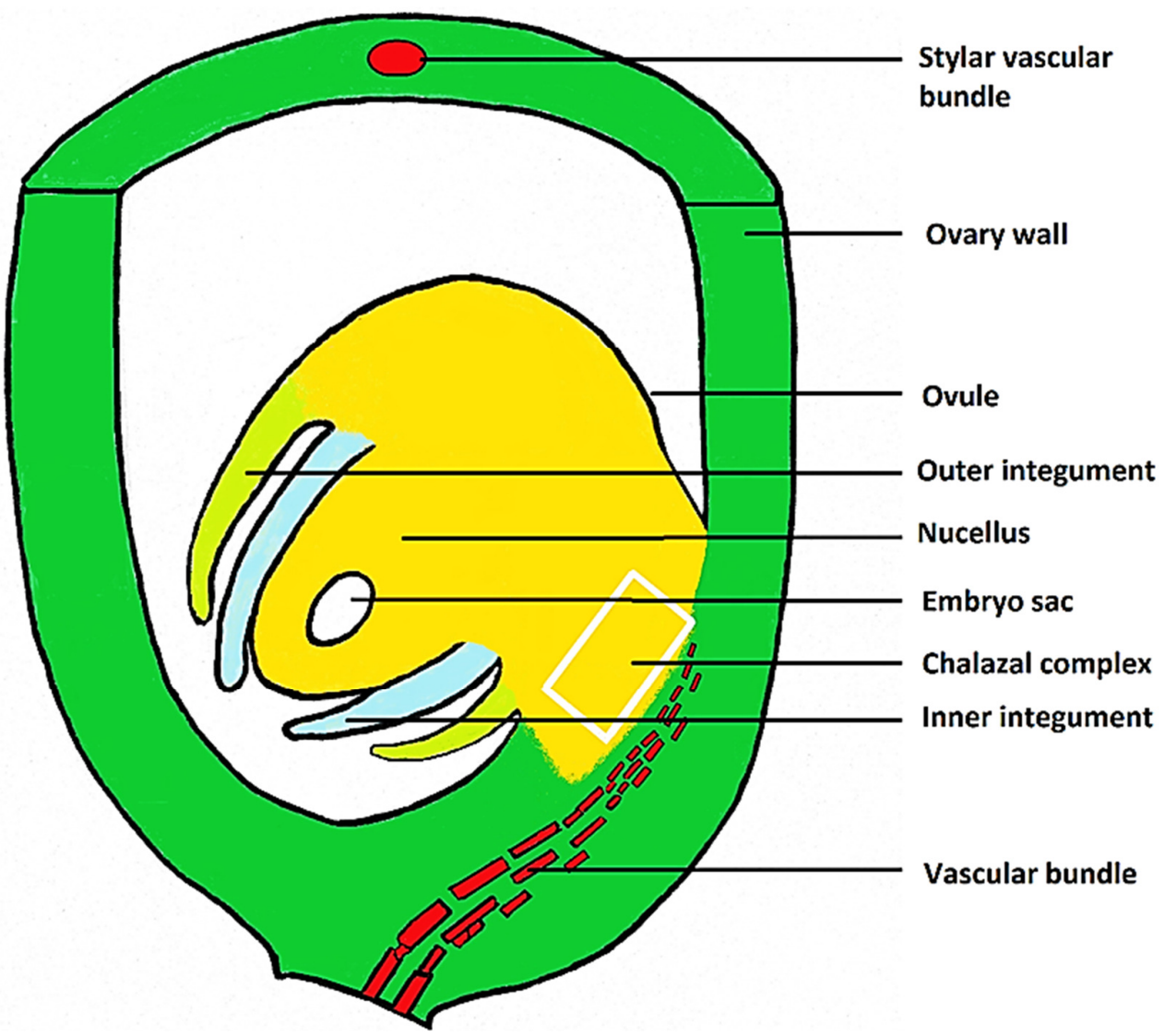

Figure 2 Diagrammatic representation of a pre-anthesis ovary showing its organs and tissues. The ovular vascular trace from the pedicel ends at the base of the ovary

During early stages of floral development, the ovule is erect in position. Artschwager (1949) has shown that due to unequal growth of the nucellus the ovule become anatropous prior to anthesis. The rectangular region marked as 'chalazal complex' in Figure 2 is a highly complex tissue that plays a major role in supply of nutrients to the developing embryo and endosperm. Although not clearly distinguishable as separate entities this region consists of the chalaza where the integuments and the nucellus join with a funicle; a highly reduced funicle which attaches the ovule to a placenta; and the placenta which is a part of the ovary wall. Typically, a scar tissue known as the hilum is seen on a mature seed at the point of attachment of the seed to the funicle. A hilum can be identified even in young ovaries by the differential staining of a region between the vascular tissue 
and the nucellar projection, labeled as the 'pigment strand' in Figure 3. This region has also been described as the 'black layer' and 'dark closing layer' in literature; the external visualization of the dark closing layer indicates the time of physiological maturity and the date of maximum dry weight accumulation (Eastin et al., 1973; Giles et al., 1975). Figure 3 is a diagrammatic representation, in longitudinal section, of a caryopsis about 20 DAF and still actively importing storage material.

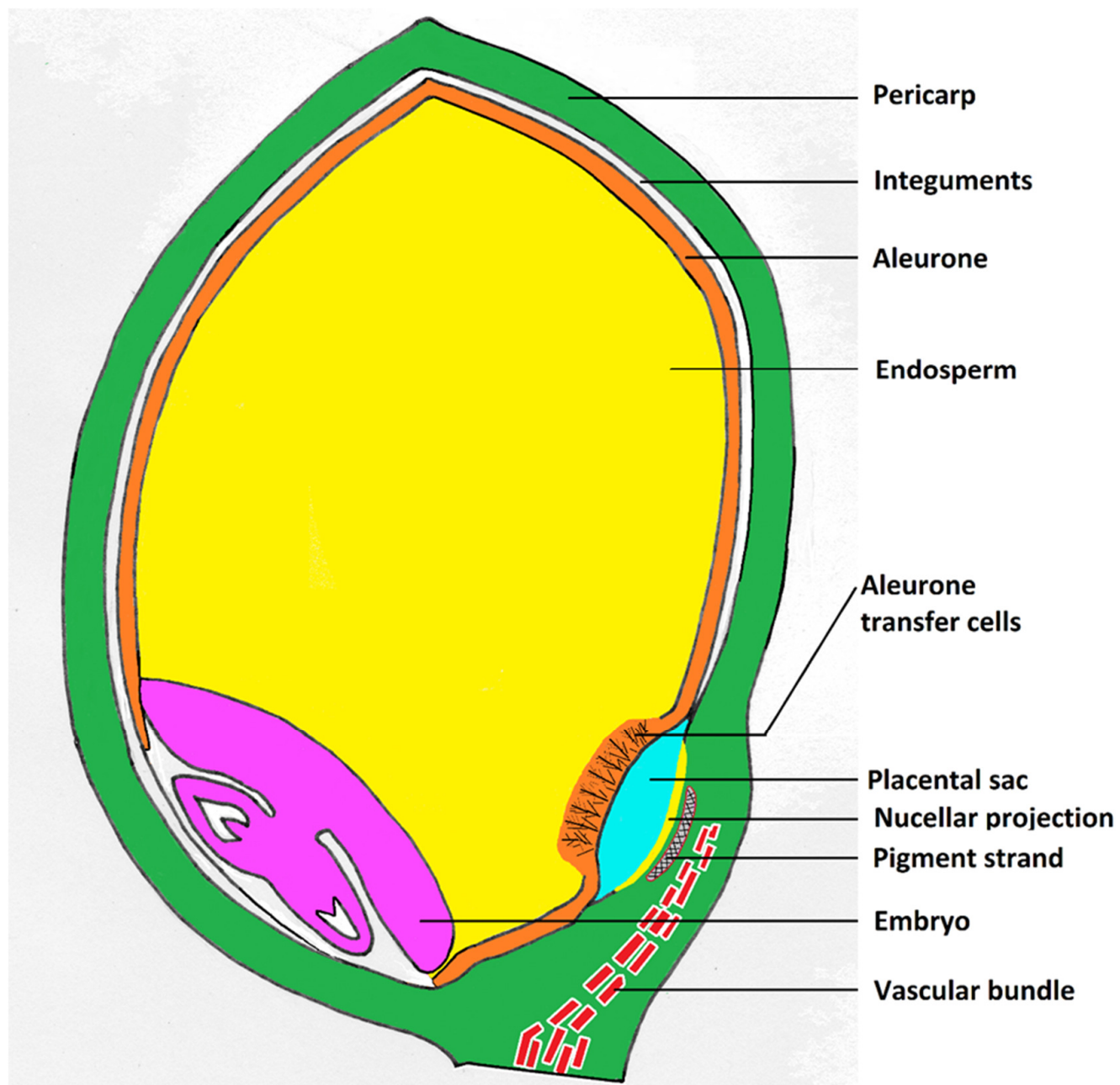

Figure 3. Diagrammatic longitudinal section of a caryopsis about 20 DAF showing embryo, endosperm and aleurone transfer cells and the differentiated chalazal complex

The pericarp, ovular vascular trace, pigment strand and nucellar projection constitute the maternal tissues. The triploid endosperm with aleurone layer and aleurone transfer cells, and the diploid embryo constitutes the filial tissues.

The embryo sac region is now filled with a diploid embryo and surrounding triploid endosperm tissue. The outer most layer of the endosperm consists of aleurone cells. The chalazal complex region reveals, in addition to the pigment strand, the presence of a nucellar projection and a placental sac. Nutrient transport from the vascular bundles occurs through vascular parenchyma cells, the pigment strand and the nucellar projection into the placental sac. Aleurone transfer cells then transport the material into the two major sinks, the embryo and the endosperm (Figures 3, 7d, 9). The aleurone transfer cells have also been described as the 'basal endosperm transfer cells' (Wang et al., 2012). Becraft and Gutierrez-Marcos (2012) use the term 'placento-chalazal tissue' to describe the chalazal complex. The placental sac was studied in detail by Maness and McBee (1986) and more recently by Wang et al. (2012). The placental, also described in literature as 
'endosperm cavity', is in fact neither placental nor endosperm in origin. It is a cavity formed by the dissolution of some layers of cells of the nucellar projection. Unlike in wheat, but as in maize, the major vascular bundles terminate at the base of the ovary. In wheat it extends thought the length of the ventral side of the ovary. In wheat, a prominent ventral groove, known as the crease, is visible along the chalazal complex. Since the vasculature terminates at the base of the ovary in sorghum, the crease region too is restricted to the basal portion of the developing caryopsis. In fully mature and dry caryopsis this basal region consisting of collapsed cells of the chalazal complex is described as 'chalazal pad' or 'placental pad' (Rost et al., 1984).

\section{Anatomy and histochemistry of the caryopsis}

The two integuments possess two layers of cells except at the proximal funicle region where they are multilayered, up to 7 layers in the outer integument. The outer integument is obliterated within 3 DAF. The inner integument tends to persists up to 10-15 DAF when the endosperm cellularization is complete and the aleurone cells are differentiating. The cuticular remnants of the integuments constitute the seed coat of the caryopsis. Cultivars such as 'Framida' accumulate proanthocyanidin tannins within the cells of the inner integument (tegmen) which impart deep red color to the seed coat. (Figure 1c). Tannin can also be localized by the nitroso reaction (Figure 6j).

At anthesis the ovary wall consists of 12-15 layers of cells. The inner epidermis differentiates into rounded cells that are elongated parallel to the long axis of the ovary and are known as tube cells (Figure 4h, 9). Immediately adjacent the inner epidermis is 3-4 layers of cells of the ovary wall that differentiate into crosscells. The cross-cells elongate perpendicular to the long axis of the tube cells and develop intercellular spaces (Figure 9). The cross-cells show intense auto fluorescence in red when excited with blue light due to the presence of chlorophyll (Figure 4i). By 10 DAF, both tube and cross-cells are well differentiated and cross-cells possess a number of amyloplasts. Cross-cells are in organic contact with the parenchyma cells associated with the vascular traces that terminate at the base of the ovary. It is likely that cross-cell photosynthates are transferred to the developing endosperm and embryo. Waniska (2000) has reported that the tube cells conduct water during grain germination while the outer cross cells form a layer that impedes moisture loss.

Starch is present in the young ovary wall but not in the nucellus or the integuments (Figure 4a, b). By 3 DAF the nucellus is completely replaced by the enlarging embryo sac enclosing the endosperm; however, starch accumulation is not noticeable at this stage. In 5-day-old caryopsis starch can be localized in the peripheral layers of the endosperm while depletion of starch can be observed in the pericarp. At this stage chlorophyll is still present in several layers of outer and inner pericarp; a middle zone of pericarp has a little or no chlorophyll (Figure 4c). Chloroplasts with starch are restricted to the cross cells in 10-day-old caryopsis. Between 20-30 DAF the pericarp starch is completely depleted even as the endosperm cells are filled with starch grains (Figure 4d). The crease region with black layer is clearly delineated at this stage (Figure 4e).

The diploid embryo and the triploid endosperm are the two sinks in a caryopsis (Figure 3). Cereal endosperm consists of four major cell types: central starchy endosperm, aleurone layer, subaleurone layer, aleurone or endosperm transfer cells, and embryo-surrounding cells (Olsen, 2004). All these cell types except the embryo-surrounding cells have been described in sorghum. Besides carbohydrates which constitute about $70 \%$ of dry grain weight other major nutrients imported into the endosperm and embryo are proteins, lipids and minerals. All these components can be localized using various histochemical and microscopic procedures in the endosperm as well as the scutellum, plumule and radicle of the embryo (Figures 5-7). Lipids for example can be easily visualized using bright field dyes such as Sudan and Oil Red and fluorochromes such as Nile Blue A, Nile Red and Rhodamine B (Figure 5 b, c, f, h, i). 

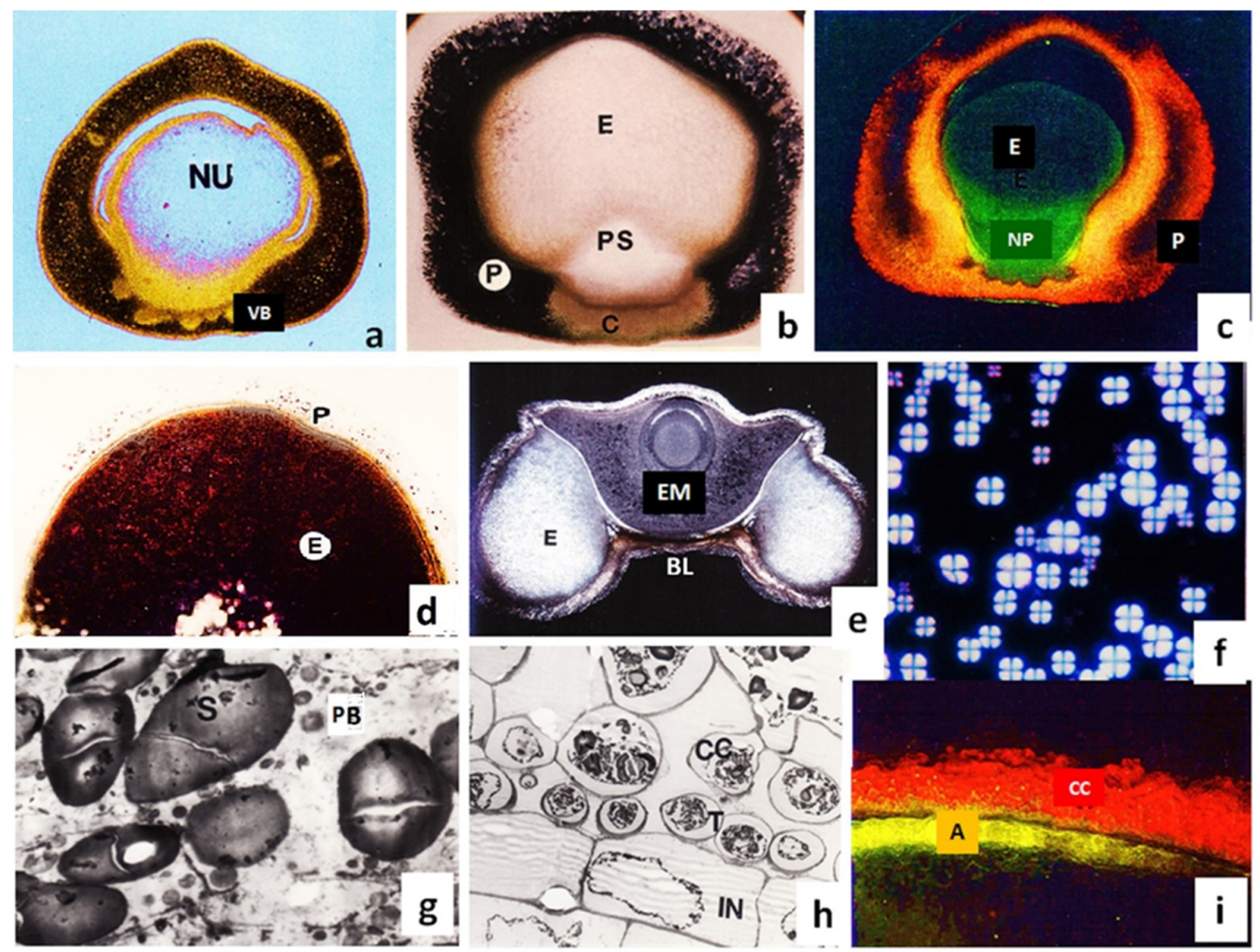

Figure 4. (a-i) Starch in sorghum ovary

$(\mathbf{a}, \mathbf{b})$ Free-hand T.S of caryopsis 1 and 3 DAF. Stained with $\mathrm{I}_{2} \mathrm{KI}$ showing starch in pericarp. Basal ovular vascular bundles and two lateral vascular bundles are seen in $(\mathbf{a})$. X35, 50. (c) Free-hand T.S. of caryopsis 5 DAF, unstained and excited with blue light showing intense autofluorescence of inner and outer pericarp due to the presence of chloroplasts. 40x. (d) Free-hand T. S. of caryopsis 20 DAF stained with $\mathrm{I}_{2} \mathrm{KI}$ showing abundant starch in endosperm and near total depletion of starch in pericarp. 40x. (e) Mature caryopsis in T.S. through the embryo region. Unstained section viewed between crossed polarizers showing starch appearing bright against dark background. Black layer is seen below the embryo in the crease region. 30x. (f) Simple starch grains squeezed out of 10-dayold endosperm and viewed between crossed polarizers. Typical Maltese Cross pattern is evident. 380x. (g) EM of an endosperm cell with starch grains and protein bodies. 2460x. (h) EM of inner pericarp of caryopsis 15 DAF. Tube and cross cells of pericarp and a few cells of inner integument are seen. Starch is present only in the pericarp cells. 3070x. (i) Autofluorescence of chlorophyll in cross cells of inner pericarp. T.S. section of caryopsis $10 \mathrm{DAF}$, excited with blue light. 100x.

(A, aleurone; BL, black layer; C, chalazal complex; CC, cross cell; E, endosperm; EM, embryo; NP, nucellar projection; NU, nucellus; P, pericarp; PB, protein body; PS, placental sac; T, tube cell; VB, vascular bundle.) 

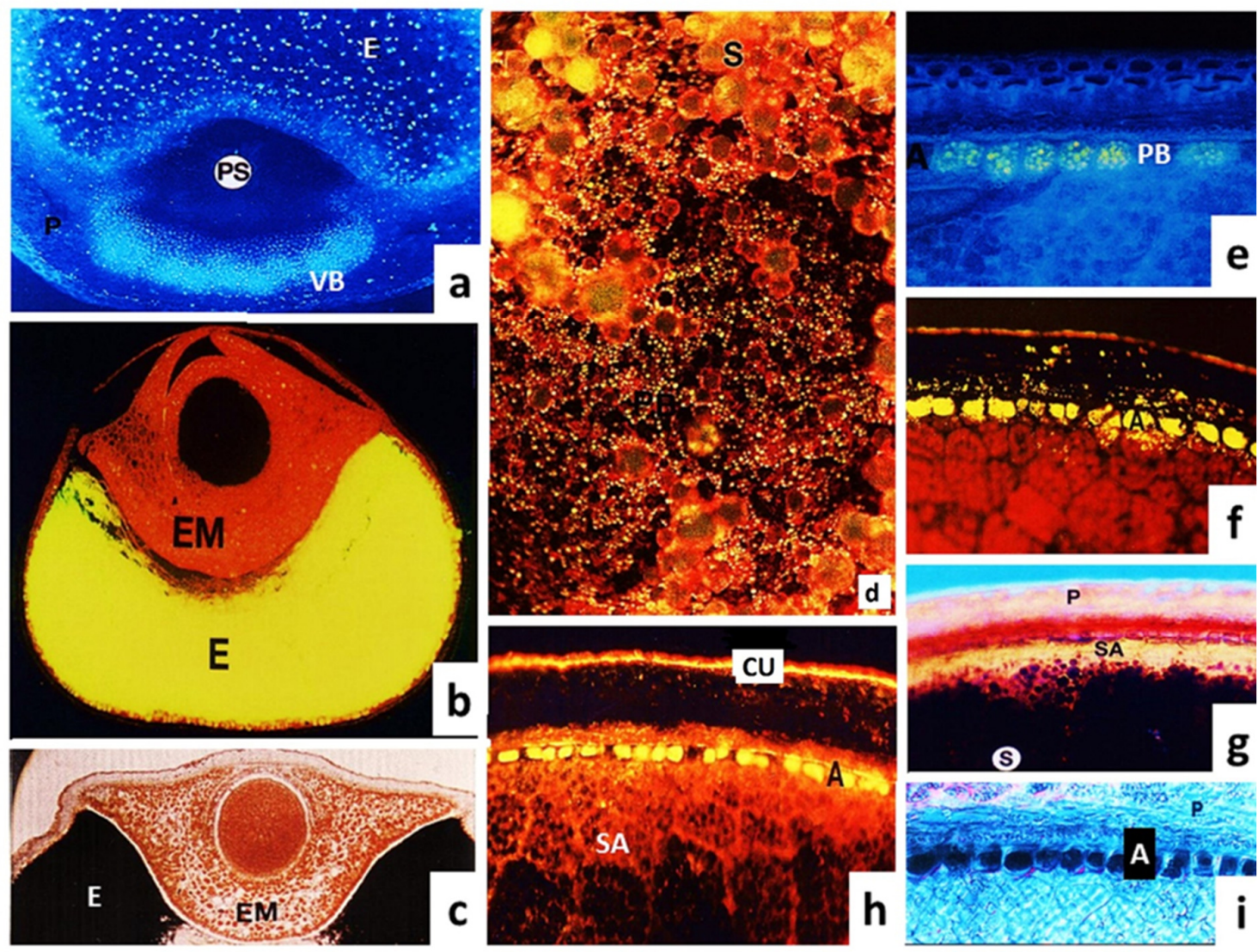

Figure 5. (a-i) Localization of nuclei, protein and lipids

(a) T. S. of caryopsis 15 DAF stained with 4,6-diamidino-2-phenylindole (DAPI), excited with UV light showing densely packed nuclei in the vascular parenchyma and cells, and distribution of triploid nuclei in endosperm. 100x. (b) Free-hand T.S. of caryopsis stained with Coriphosphine and excited with blue light. Starch in endosperm fluoresces yellow while lipids in embryo fluoresce in orange-red. 40x. (c) Mature caryopsis simultaneously stained with $\mathrm{I}_{2} \mathrm{KI}$ and Sudan IV showing distribution of starch in endosperm and lipids in embryo. 30x. (d) Smear from 25-day-old endosperm stained with Acridine Orange and excited with blue light. Protein bodies fluoresce yellow-green; larger starch grains appear greenish. 400x. (e) Protein bodies (aleurone grains) in aleurone cells stained with Barbituric Acid and excited with UV light. 180x. (f) Lipids in aleurone cells fluoresce yellow when stained with Nile Blue A and excited with blue light. 180x. (g) Free-hand T.S. of cv. 'Framida' stained with $\mathrm{I}_{2} \mathrm{KI}$, viewed in Nomarski DIC mode. Starch is present in endosperm. Two layers of sub-aleurone rich protein bodies show no evidence of starch. 150x. (h) Free-hand T.S. of mature caryopsis stained with Nile Red, excited with blue light. Lipid in aleurone cells and cuticular layers of outer and inner pericarp all fluoresce in yellow. 170x. (i) Lipids in aleurone cells stained with Sudan Black, photographed in DIC mode. 140x.

(A, aleurone; CU, cuticle; E, endosperm; EM, embryo; P, pericarp; PB, protein bodies; PS, placental sac; S, starch; SA, subaleurone; VB, vascular bundle.)

The aleurone and the embryo accumulate large quantities of mineral nutrients. Myo-inositol hexaphosphate bound to cations such as $\mathrm{Ca}, \mathrm{K}$ and $\mathrm{Mg}$ occur as discrete bodies known as phytin granules. Alizarin Red can be used both as bright field or fluorescent reagent to localize phytin, while $\mathrm{K}, \mathrm{Mg}$ and $\mathrm{Fe}$ can be revealed by sodium cobalitinitrite, magneson and Prussian Blue reagents, respectively (Figure 6 a-f, i). Nuclear DNA in the cells of caryopsis can be localized with 4, 6-diamidino-2-phenylindole (DAPI) (Figure 5a). Enzymes such as esterase and succinic dehydrogenase are very active in different tissues at different stages of caryopsis development. Enzymes too can be localized with histochemical procedures (Figure $6 \mathrm{~g}, \mathrm{~h}$ ). Cell walls of sorghum pericarp, aleurone, and endosperm exhibit a blue autofluorescence mainly due to the presence 
of esters of ferulic acid (Waniska, 2000). Chlorophyll autofluoresces in red when excited with blue light (Figure $4 c, 8 a)$.
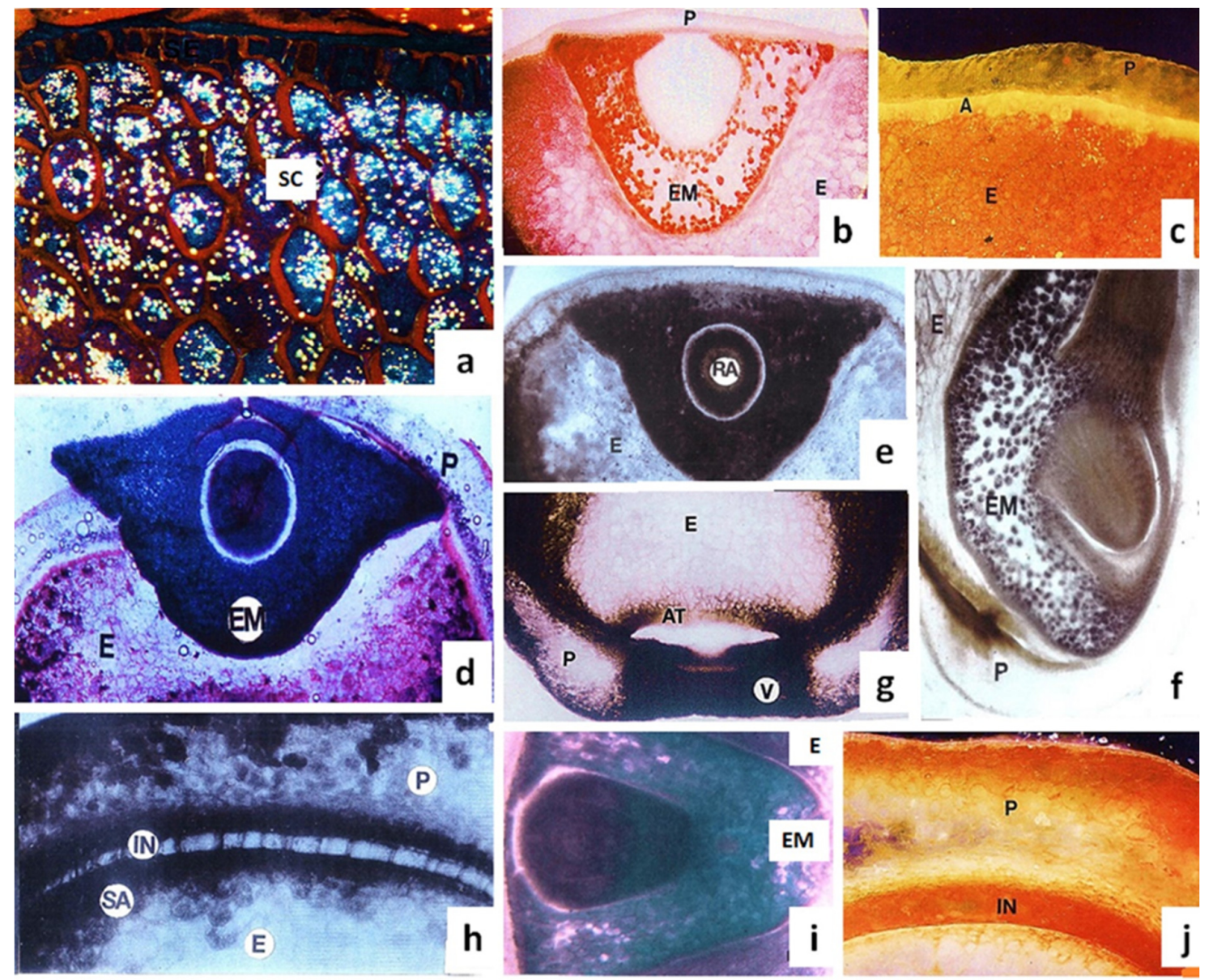

Figure 6. Phytin, minerals, tannin, enzyme activity in sorghum caryopsis

(a) Microtome section of mature caryopsis stained with Safranin and Fast Green. Between crossed polarizers aleurone grains appear bright in cells of the scutellum. 200x. (b) Free-hand T.S. of mature caryopsis stained with Alizarin Red. Phytin appears red in embryonal cells. 30x. (c) Free-hand T.S. of mature caryopsis stained with Alizarin Red, excited with blue light, revealing phytin granules in the aleurone cells. 160x. (d) Distribution of magnesium, localized by Magneson Reagent in sorghum cv. IS-18161. 40x. (e) Abundant potassium in the embryo, localized by Sodium Cobalitinitrite Reagent. 40x. (f) L.S of caryopsis showing the distribution of magnesium in embryo region localized by Magneson Reagent. 40x. (g) High activity of esterase is noticed in vascular region, chalazal complex, endosperm transfer cells, outer endosperm layers and pericarp tissue in 10-day-old caryopsis. 50x. (h) Esterase activity compartmentalized in outer and inner pericarp and aleurone and subaleurone layers, but not in the inner integument. 190x. (i) Localization of iron with Potassium Ferro cyanide-HCL reagent in embryo region. 50x. (j) Caryopsis of cv. 'Framida' section 10 DAF and stained with Nitroso reaction revealing presence of tannin in outer pericarp and inner integument layers. 250x.

(A, aleurone; AT, aleurone transfer layer; E, endosperm; EM, embryo; IN, inner integument; P, pericarp; RA, radicle; SA, subaleurone layer; SC, scutellum; V, vascular region)

\section{Transport pathway in sorghum}

Grain-filling studies in cereals and legumes have established that there is no symplastic continuity between the maternal and filial tissues and that apoplastic transport accounts for the movement of storage material into the sink organs, embryo and endosperm (Maness and McBee, 1986; Krishnan and Dayanandan, 
2003; Wang et al., 2012; Bihmidine et al., 2013). The path and mode of transport of material can be investigated by examining the structure as well as movement of dyes through vascular and other tissues.

The crease region is located where the pedicel ends and the ovary begins and where the ovular vascular bundles terminate (Figures 2, 3, 7, 9). The chalazal complex has been shown to possess high activities of expression of genes involved in carbohydrate metabolism, especially cell wall invertase (Chourey et al., 2008). Symplastic transport of sucrose, water, amino acids and minerals from the vascular tissues into the apoplastic placental sac should pass through the vascular parenchyma cells, pigment strand, chalaza and nucellar projection (Figure 3, 7a, d, 9). From the placental sac apoplastic transfer loads the nutrient material into the aleurone transfer cells. A placental sac is clearly visible by $4-5$ DAF due to the dissolution of some cells of the nucellus (Figure 7c). The remaining cluster of nucellar cells constitutes the nucellar projection. The structural features of the placental sac and the associated tissues are clearly distinguishable in caryopsis 10 DAF (Figure $7 \mathrm{a}, \mathrm{d})$. Cellularization of the endosperm is already nearing completion by 3 DAF followed by further cell divisions and wall thickening. Aleurone transfer cells appear about 5 DAF in the outermost layer of endosperm adjacent the placental cavity. This outer layer is continuous with the single layer of aleurone cells that occurs throughout the rest of the endosperm (Figures 3,9). One or two layers of aleurone transfer cells undergo cell wall invagination and multiple folding resulting in extensive network (Figure $7 \mathrm{c}-\mathrm{e}$ ). By about 25 DAF the aleurone transfer cell wall thickenings lack integrity and show more intense staining. By this stage deposition of starch in the endosperm has progressed from the center to the cells adjacent the aleurone transfer cell and transport of material into sinks is almost complete.

Anatomical and histochemical features of the chalazal complex of the crease region during active grainfilling period, 15-20 DAF, are illustrated in figures 9. Starting from about ten DAF the aleurone transfer cells accumulate carbohydrates, soluble proteins and show strong esterase activity. Towards the end of maximum grain-filling period, about $25 \mathrm{DAF}$, lipids are present in the pigment strand, aleurone layer and embryo; no significant amounts of lipids occur in the aleurone transfer cells. The nucellar projection layers are reduced to 2-3 by 15 DAF. The placental sac is obliterated due to the growth of the embryo, a portion of which now lies next to the black layer. By about $30 \mathrm{DAF}$, grain-filling is complete and the crease region appears black because of the deposition of tannin (Figure 7g). The black layer includes cells of the pericarp and the chalazal complex, including the lipid -containing pigment strand.

\section{Dye movement}

By tracing the movement of 5(6) carboxyfluorescein and fluorescein through the spikelets, assimilate pathways can be inferred. The pattern of movement of fluorochromes supplied for $2-5 \mathrm{~h}$ through the basal cut ends of tertiary spikelets at different stages of caryopsis are shown in figure 8. Both the fluorochromes show similar pattern of movement in the crease region and adjacent pericarp tissues. In unstained caryopsis 5 DAF the pericarp autofluoresces in red due to the presence of chlorophyll. Vascular traces, nucellar projection and endosperm tissues fluoresce in green (Figure 8a). It is not clear if the movement into pericarp is due to diffusion at this early stage of caryopsis development (Figure $8 \mathrm{~d}$ ). The pattern of dye movement is better defined in 10$15 \mathrm{DAF}$ caryopses when the rate of grain-filling is at its maximum (Figure 8b, c, e). At this stage fluorochrome movement into pericarp tissue is limited to the region immediately surrounding the chalazal complex including the phloem and the aleurone transfer cell layers. Dye movement continues even $25 \mathrm{DAF}$ in caryopsis that is nearing physiological stage of maturity. For the next 5 days dye can be observed in the aleurone and aleurone transfer cells (Figure 8f, g). The placental sac is intact and there is dye movement from the aleurone transfer cells to all the aleurone cells. At all stages of transport, the pigment strand and the placental sac remain nonfluorescent indicating rapid transport by pumping through the pigment strand and emptying out from the placental sac. 


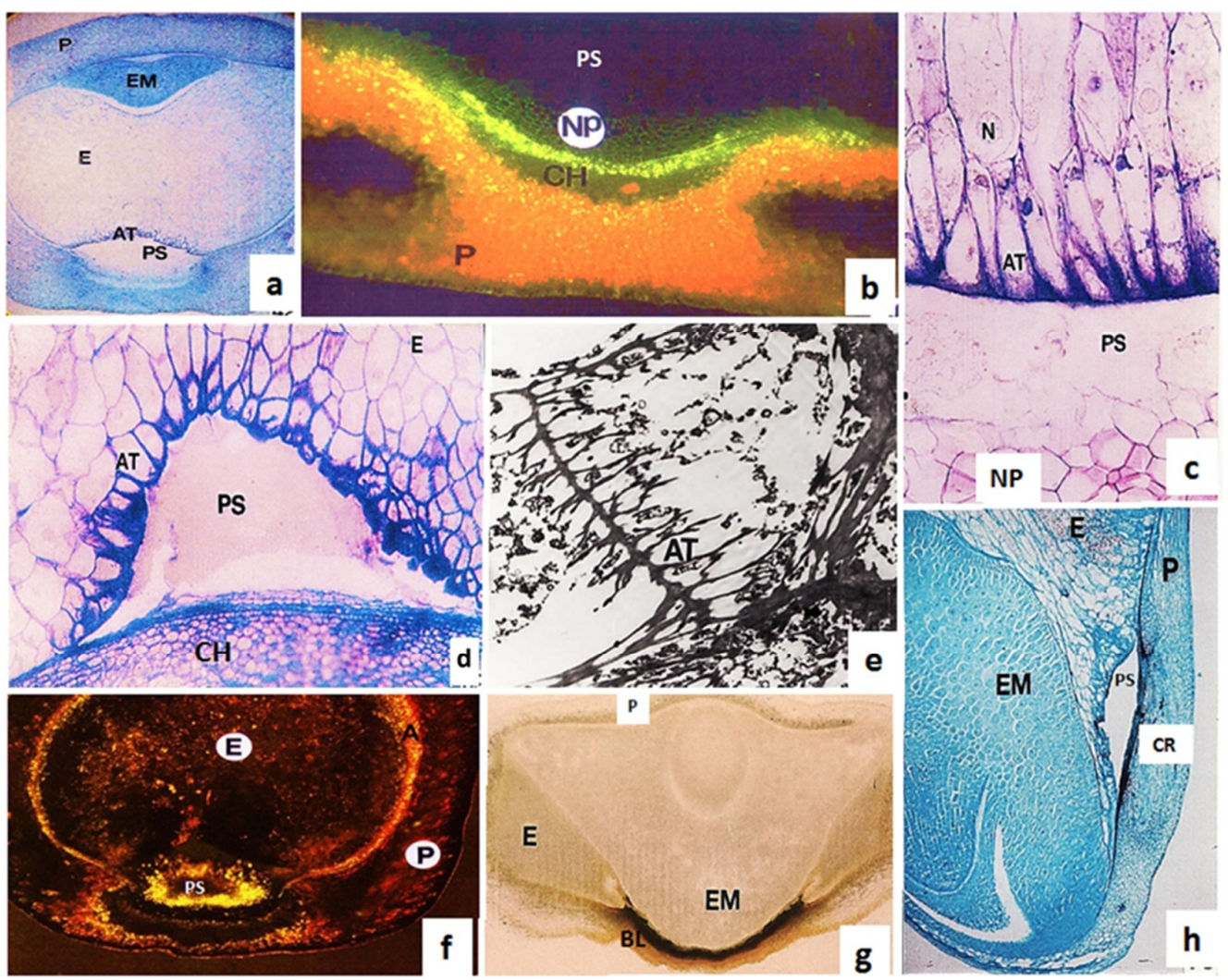

Figure 7. Anatomy and histochemistry transport structures

(a) Low magnification view of caryopsis 10 DAF showing the position of embryo and endosperm in relation to placental sac and aleurone transfer layer. 40x. (b) Free-hand transverse sections excited with blue light. Chlorophyll autofluoresces in red in pericarp region. Yellow fluorescence between chalazal and nucellar projection is due to the presence of lipids in the pigment layer. 180x. (c) T.S. of 5-day-old caryopsis. Cells between nucellar projection and aleurone transfer cells are lysed to create the placental sac. Aleurone transfer cells show wall thickenings. 320x. (d) 15day-old caryopsis; thin plastic section near crease region showing large placental sac and aleurone transfer cells. 100x. (e) TEM view of cell wall ingrowths in periclinal walls of aleurone transfer cells in caryopsis 8 DAF. 10,500x. (f) T.S. of caryopsis 25 DAF revealing prominent pigment layer (yellow fluorescence due to lipids) as the placental sac begins to shrink. Lipid in aleurone layer also fluoresces. Stained with Nile blue A, excited with blue light. 40x. (g) 30-day-old unstained caryopsis section showing black layer. 30x. (h) 20-day-old grain in wax embedded L.S. showing the small placental sac between embryo and chalazal complex. 40x.

(A, aleurone; AT, aleurone transfer cell; BK. Black layer; CH, chalazal complex; CR, crease region; E, endosperm; EM, embryo; N, nucleus; NP, nucellar projection; P, pericarp; PS, placental sac.) 

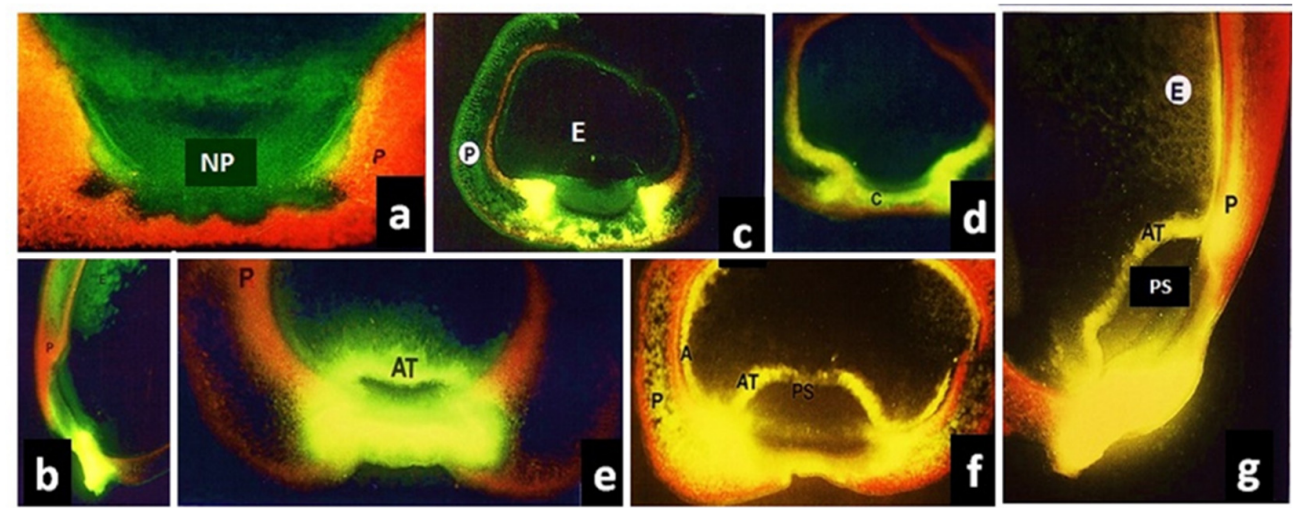

Figure 8. Transport of fluorochromes in caryopsis

All are free-hand fresh sections. (a) T.S. of control caryopsis, 5 DAF, showing intense autofluorescence of chlorophyll in pericarp when excited with blue light. Vascular bundles lack chlorophyll. 75x. (b) L.S. of caryopsis, 10 DAF, showing fluorescence of fluorescein after $2 \mathrm{~h}$ of transport. Excited with blue light. The dye accumulates in the vascular traces that terminate at the base of the caryopsis. 40x. (c) After $3 \mathrm{~h}$ of transport fluorescein has moved through phloem region and part of the pericarp on either side of the placental sac in 10-day-old caryopsis excited with blue light. 40x. (d) T.S. of caryopsis, $5 \mathrm{DAF}$, showing fluorescence in chalazal complex and adjacent pericarp tissues after transport of fluorescein for $3 \mathrm{~h}$ and excited with blue light. 50x. (e) T.S. of caryopsis, $15 \mathrm{DAF}$, showing intense fluorescence of 5 (6) carboxyfluorescein (CF) in the vascular trace region and aleurone transfer cells after $5 \mathrm{~h}$ of movement. Excited with blue light. 50x. (f) T.S. of caryopsis, $30 \mathrm{DAF}$, showing fluorescence of CF in cells of the aleurone layer and aleurone transfer cells. Excited with blue light after $5 \mathrm{~h}$ of dye transport. 50x. (g) L.S. of caryopsis, 30 DAF, showing fluorescence of CF in basal and chalazal complex region, aleurone transfer cells, and aleurone cells after $5 \mathrm{~h}$ of transport. Excited with blue light. 50x. (A, aleurone cell; AT, aleurone transfer layer; C, chalazal complex; E, endosperm; NP, nucellar projection; P, pericarp; PS, placental sac.)

\section{Discussion}

Developmental, ultrastructural, physiological and molecular studies and microperfusion techniques have established the development of ovary and caryopsis in cereal grasses including sorghum (Maness and McBee, 1986; Wang et al., 2012). These studies have also revealed the lack of symplastic continuity between maternal and filial tissues and the importance of cells and tissues involved in transfer of solutes to the diploid embryo and the triploid endosperm (Felker and Shannon, 1980; Porter et al., 1987; Wang and Fisher, 1994a and b; Krishnan and Dayanandan, 2003; Olsen, 2004, 2007; Kladnik et al., 2006; Jain et al., 2008; Sabelli and Larkins, 2009; Becraft and Gutierrez-Marcos, 2012). Programmed cell death (PCD) seems to be an integral part of caryopsis development that is initiated immediately after pollination affecting integuments and ending in chalazal complex and endosperm cells. Becraft and Gutierrez-Marcos (2012) have suggested the PCD is linked to a raise in ethylene production and the end of starch accumulation.

Figure 9 of the crease region in sorghum based on the present study shows the important structures involved in transport of storage material over a period of about $30 \mathrm{DAF}$.

Grasses seem to have evolved different strategies for transport of storage material into the caryopsis, only a few of which is now known to us, mainly through the study of cereal grasses. The vascular bundle supplying nutrients terminate at the base of the ovary in sorghum and other $\mathrm{C}_{4}$ grasses such as maize, teosinte and Job's tears. In contrast, $\mathrm{C}_{3}$ grasses like wheat, barley, rice and bamboo (Bambusa arundinacea) possess vascular bundles that traverse the entire length of the ovary (Krishnan and Dayanandan, 2003). While an apoplastic placental sac is present in sorghum, wheat and barley such a cavity is not obvious in maize, rice. However, a small placental cavity has been reported in bamboo (Jonathan, 1999); and the presence of such cavities may be revealed when more cultivars of maize and rice are examined (Hoshikawa, 1984). In all grasses investigated transport into embryo and endosperm requires the mediation of specialized cells. In rice and bamboo, the outer 
epidermis of the nucellus remains intact and helps in transport. Cell walls of the nucellar epidermis in rice are provided with rib-like thickenings (Krishnan and Dayanandan, 2003). Nucellar epidermis is not involved in transport in sorghum. Dye movement into the single aleurone layer observed in the present study suggests that it might be an additional minor pathway of transport in sorghum. In this case the aleurone layer might be analogous to the assimilate-transporting nucellar epidermis of rice. In sorghum and other grasses some endosperm aleurone cells develop wall thickenings characteristic of transfer cells and aid in transport. Transfer cells have also been observed in nucellus, outer and inner pericarps and nucellar projection (Rost et al., 1984). An embryo-surrounding region (ESR) consisting of endosperm cells with unique cytological features and distinct gene expression reported in maize and other plants (Becraft and Gutierrez-Marcos, 2012) has not been investigated in sorghum.

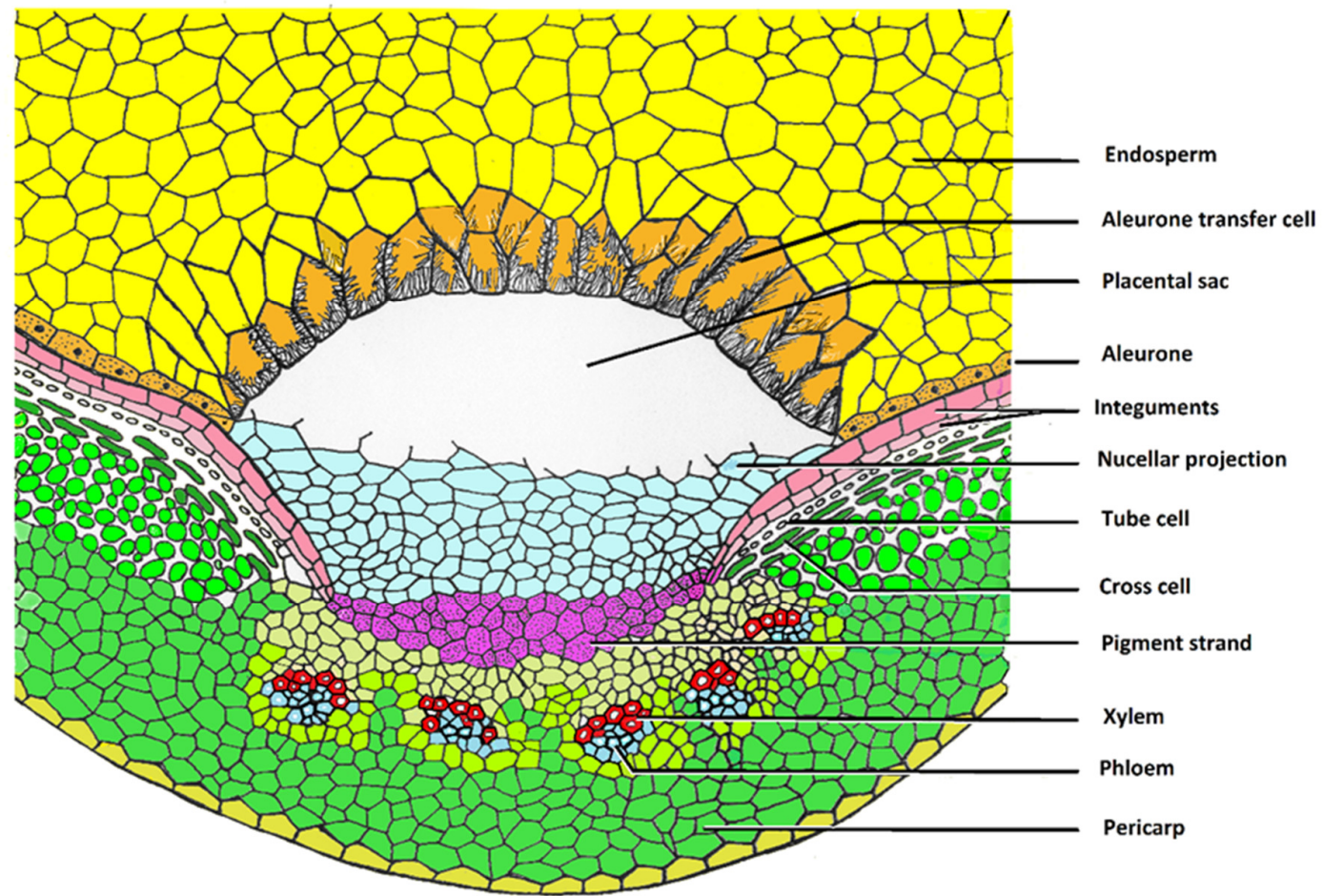

Figure 9. Diagrammatic representation of a portion of basal region of sorghum caryopsis seen in transverse section during rapid grain-filling stage (15-20 DAF)

Pericarp and basal ovular vascular bundles are shown. Chalazal region has differentiated into pigment strand and nucellar projection leading to the placental sac. Aleurone transfer cells occur next to the placental sac. Diagram is based on the various anatomical and histochemical techniques used in this study.

\section{Conclusions}

Understanding the structures involved in grain-filling is of agronomic importance. It has been shown that dry grain weight is correlated with ovary volume at anthesis and that larger ovaries have higher rates of filling during caryopsis development and contains more endosperm cells and starch granules than normal-sized ovaries (Yang et al., 2009). There is a need to examine the transport structures, pathways and mechanisms in more species of grasses in order to understand how a broad spectrum of grain-filling strategies might have helped in the evolutionary of the grass family. There is also need to adopt standardized terminologies to describe the chalazal complex (placenta-chalazal region), crease region (chalazal pad, placental pad), pigment strand 
(dark and black layer), placental sac (endosperm cavity) and aleurone transfer cells (endosperm transfer cells, basal endosperm transfer cells).

\section{Authors' Contributions}

Both authors read and approved the final manuscript.

\section{Acknowledgements}

This research received no specific grant from any funding agency in the public, commercial, or not-forprofit sectors.

\section{Conflict of Interests}

The authors declare that there are no conflicts of interest related to this article.

\section{References}

Artschwager E, McGuire RC (1949). Cytology of reproduction in Sorghum vulgare. Journal of Agricultural Research $78(2): 659-673$

Becraft PW, Gutierrez-Marcos J (2012). Endosperm development: dynamic processes and cellular innovations underlying sibling altruism. WIREs Developmental Biology 1(4):579-593. https://doi.org/10.1002/wdev.31

Bihmidine S, Hunter CT III, Johns CE, Koch KE, Braun DM (2013). Regulation of assimilate import into sink organs: update on molecular drivers of sink strength. Frontiers in Plant Science 4:177. https://doi.org/10.3389/fpls.2013.00177

Clark G (1981). Staining procedures. Williams and Wilkins, Baltimore.

Cochrane MP, Duffus CM (1979). Morphology and ultrastructure of immature cereal grains in relation to transport. Annals of Botany 44(1):67-72. https://doi.org/10.1093/oxfordjournals.aob.a085707

Conn HJ (1977). Biological stains. In: Lillie RD (Ed). Williams and Wilkins, St. Louis.

Cook H, Oparka KJ (1983). Movement of fluorescein into isolated caryopses of wheat and barley. Plant, Cell \& Environment 6(3):239-242. https://doi.org/10.1111/1365-3040.ep11587641

Davis RW, Smith JD, Cobb BG (1990). A light and electron microscope investigation of the transfer cell region of maize caryopsis. Canadian Journal of Botany 68(3):471-479. https://doi.org/10.1139/b90-063

Eastin JD, Hultquist JH, Sullivan CY (1973). Physiologic maturity in grain sorghum. Crop Science 13(2):175-178. https://doi.org/10.2135/cropsci1973.0011183X001300020008x

Ebenezer GAI (1997). Histochemical and developmental studies on germinating rice grains. PhD Thesis, University of Madras, India.

FAO (1995). Sorghum and millets in human nutrition. Food and Agriculture Organization of the United Nations, Rome.

Felker FC, Shannon JC (1980). Movement of 14C-labelled assimilates into kernels of Zea mays L.: an anatomical examination and microautoradiographic study of assimilate transfer. Plant Physiology 65(5):864-870. https://www.jstor.org/stable/4266247

Fischer KS, Wilson GL (1975a). Studies on grain production in Sorghum bicolor (L.) Moench. III. The relative importance of assimilate supply, grain growth capacity and transport system. Australian Journal of Agricultural Research 26(1):11-23. https://doi.org/10.1071/AR9750011

Fischer KS, Wilson GL (1975b). Studies on grain production Sorghum bicolor (L.) Moench. V. Effect of planting density on growth and yield. Australian Journal of Agricultural Research 26(1):31-41. https://doi.org/10.1071/AR9750031 
Fisher DB, Wang N (1993). A kinetic and micro autoradiographic analysis of (14C) sucrose import by developing wheat grains. Plant Physiology 101(2):391-398. https://doi.org/10.1104/pp.101.2.391

Fulcher RG (1982). Fluorescence microscopy of cereals. Food Microstructure 1(2):7. https://digitalcommons.usu.edu/foodmicrostructure/voll/iss $2 / 7$

Gibson PT, Schertz KF (1977). Growth analysis of a sorghum hybrid and its parents. Crop Science 17(3):387-391. https://doi.org/10.2135/cropsci1977.0011183X001700030011X

Giles KL, Bassett CM, Eastin JD (1975). The structure and ontogeny of the hilum region in Sorghum bicolor: Australian Journal of Botany 23(5):795-802. https://doi.org/10.1071/BT9750795

Grignon N, Touraine B, Durand M (1989). 6(5)carboxyfluorescein as a tracer of phloem sap translocation. American Journal of Botany 76(6):871-877. https://www.jstor.org/stable/2444542

Harris N, Oparka KJ (1994). Plant cell biology: a practical approach. Oxford University Press, New York.

Hawes C (1994). Electron microscopy. In: Harris N, Oparka KJ (Eds). Plant cell biology: practical approach. Oxford University Press, New York pp 69-96.

Hoshikawa K (1984). Development of endosperm tissue with special reference to the translocation of reserve substances in cereals. Japanese Journal of Crop Science 53(1):153-162. https://doi.org/10.1626/jcs.53.64

Jain M, Chourey PS, Li QB, Pring DR (2008). Expression of cell wall invertase and several other genes of sugar metabolism in relation to seed development in sorghum (Sorghum bicolor). Journal of Plant Physiology 165(3):331-344. https://doi.org/10.1016/j.jplph.2006.12.003

Jensen WA (1962). Botanical histochemistry: principles and practice. Freeman and Co., San Francisco.

Johari RP, Mehta SI, Naik MS (1977). Changes in carbohydrate protein fractions and leucine-(C14) incorporation during sorghum grain development. Phytochemistry 16(3):311-314.

Jonathan P (1999). Histochemical studies on the caryopsis of bamboo (Bambusa arundinacea (Retz) Willd). M.Phil. Thesis, University of Madras, India.

Kladnik A, Chourey PS, Pring DR, Dermastia M (2006). Development of the endosperm of Sorghum bicolor during the endoreduplication-associated growth phase. Journal of Cereal Science 43(2):209-215. https://doi.org/10.1016/j.jcs.2005.09.004

Krishnan S, Ebenezer GAI, Dayanandan P (2001). Histochemical localization of storage components in caryopsis of rice (Oryza sativa L.). Current Science 80(4):567-571. https://www.jstor.org/stable/24104248

Krishnan S, Dayanandan P (2003). Structural and histochemical studies on grain-filling in the caryopsis of rice (Oryza sativa L.). Journal of Biosciences 28(4):455-469. https://doi.org/10.1007/BF02705120

Maiti R (1993). Morphological traits in crop improvement: case study - sorghum. In: Wesche-Ebeling AP, Garciduenas MR, Earl PR. Publicaciones Bioligicas, Mexico pp 1-283.

Maness NO, McBee GG (1986). Role of placental sac in endosperm carbohydrate import in sorghum caryopses. Crop Science 26(6):1201-1207. https://doi.org/10.2135/cropsci1986.0011183X002600060026x

Oparka KJ (1991). Uptake and compartmentation of fluorescent probes by plant cells. Journal of Experimental Biology 42(5):565-579. https://doi.org/10.1093/jxb/42.5.565

Olsen OA (2004). Nuclear endosperm development in cereals and Arabidopsis thaliana. Plant Cell Supplement 16:S214S227. https://doi.org/10.1105/tpc.017111

Patrick JW (1983). Photosynthate unloading from seed coats of Phaseolus vulgaris L. General characteristics and facilitated transfer. Zeitschrift fur Pflanzenphysiologie 111(1):9-18. https://doi.org/10.1016/S0044$328 X(83) 80068-3$

Patrick JW, Offler CE (1995). Post-sieve element transport of sucrose in developing seeds. Australian Journal of Plant Physiology 22(4):681-702. https://doi.org/10.1071/PP9950681

Paulson IW (1968). Embryogeny and caryopsis development of Sorghum bicolor (L.) Moench. Crop Science 4(1):10-13. https://doi.org/10.2135/cropsci1969.0011183X000900010034X

Pearse AGE (1972). Histochemistry, theoretical and applied, vol. 1. Churchill Livingstone (3rd ed), London.

Pearse AGE (1980). Histochemistry, theoretical and applied, vol. 2. Churchill Livingstone (4th ed), London.

Peterson CA, Emanuel ME, Humphreys GB (1981). Pathway of movement of apoplastic fluorescent dye tracers through the endodermis at the site of secondary root formation in corn (Zea mays) and broad bean (Vicia faba). Canadian Journal of Botany 59(5):618-625. https://doi.org/10.1139/b81-087

Porter GA, Knievel DP, Shannon JC (1987). Assimilate unloading from maize (Zea mays L.) pedicel tissues. II. Evidence for regulation of unloading by cell turgor. Plant Physiology 83(1):131-136. https://doi.org/10.1104/pp.85.2.558 
Quinby JR (1972). Grain-filling period of sorghum parents and hybrids. Crop Science 12(5):690-691. https://doi.org/10.2135/cropsci1972.0011183X001200050041X

Reddy PS, Reddy BVS, Kumar AA (2009). M 35-1 derived sorghum varieties for cultivation during the post-rainy season. Journal of SAT Agricultural Research 7:1-4. http://ejournal.icrisat.org/Volume7/Sorghum_Millets/SG701.pdf

Reddy BVS, Reddy PS, Sadananda, AR, Dinakaran IE, Kumar AA, Deshpande SP, Srinivasa P (2012). Post-rainy season sorghum: constraints and breeding approaches. Journal of SAT Agricultural Research 10(1):1-12. http://ejournal.icrisat.org/Volume10/Sorghum_Millets/Postrainy.pdf

Rooney LW, Clark LE (1968). The chemistry and processing of sorghum grain. Cereal Chemistry Today 13(7):254-260.

Rooney LW, Sullins RD (1977). The structure of sorghum and its relation to processing and nutritional value. In: Dendy DAV (Ed). Proceedings of Symposium on Sorghum Millets Human Food. London: Tropical Products Institute pp 1-109.

Rooney LW, Miller FR (1982). Variation in the structure and kernel characteristics of sorghum. In: Rooney LW, Murty DS (Eds). Proceedings of the International Symposium on Sorghum Grain Quality, 28-31 October 1981. Patancheru, Andhra Pradesh, India: International Crops Research Institute for the Semi-Arid Tropics (ICRISAT) pp 143.

Rooney LW, Faubion JM, Earp CF (1983). Scanning electron microscopy of cereal grain. In: Bechtel DB (Ed). New Frontiers in Food Microstructure. Minnesota: The American Association of Cereal Chemists, Inc. pp 201-239.

Rost TI, de Artucio PI, Risley EB (1984). Transfer cells in the placental pad and caryopsis coat of Pappophorum subbulbosum Arech. (Poaceae). American Journal of Botany 71(7):948-957. https://doi.org/10.1002/j.15372197.1984.tb14161.x

Sabelli PA, Larkins BA (2009). The development of endosperm in grasses. Plant Physiology 149(1):14-26. https://doi.org/10.1104/pp.108.129437

Sanders EH (1955). Developmental morphology of the kernel in grain sorghum. Cereal Chemistry 32(1):12-25.

Schumacher W (1933). Untersuchungen uber die Wanderung des fluoresceins in den Siebrohren [Studies on the migration of fluorescein in the sieve tubes]. Jahrbuch fur Wissenchaftliche Botanik 77:685-732.

Srinivas T, Bhashyam MK, Raju GN (1985). Anatomical and chemical peculiarities caused during the translocation of solute in the developing cereal grains. Plant Physiology and Biochemistry 12(2):77-85.

Thorne JH, Rainbird RM (1983). An in vivo technique for the study of phloem unloading in seed coat of developing soyabean seeds. Plant Physiology 72(1):261-271. https://doi.org/10.1104/pp.72.1.268

Ugalde TD, Jenner CF (1990a). Route of substrate movement into wheat endosperm. I. Carbohydrates. Australian Journal of Plant Physiology 17(6):693-704. https://doi.org/10.1071/PP9900693

Ugalde TD Jenner CF (1990b). Route of substrate movement into wheat endosperm. II. Amino acids; Australian Journal of Plant Physiology 17(6):705-714. https://doi.org/10.1071/PP9900705

Vannalli, S, Kasturiba B, Naik RK, Yenagi N (2008). Nutritive value and quality characteristics of sorghum genotypes. Karnataka Journal of Agricultural Science 20(3):586-588. http://eprints.icrisat.ac.in/863/

Wall JS, Blessin CW (1969). Composition and structure of sorghum grains. Cereal Science Today 14(8). https://naldc.nal.usda.gov/download/32067/PDF

Wang N, Fisher DB (1994a). Monitoring phloem unloading and post-phloem transport by micro perfusion of attached wheat grains. Plant Physiology 104(1):7-16. https://doi.org/10.1104/pp.104.1.7

Wang N, Fisher DB (1994b). The use of fluorescent tracers to characterize the post-phloem transport pathway in maternal tissue of developing wheat grains. Plant Physiology 104(1):17-27. https://doi.org/10.1104/pp.104.1.17

Wang HL, Offler CE, Patrick JW, Ugalde TD (1994). The cellular pathway of photosynthate transfer in the developing wheat grain. I. Delineation of a potential transfer pathway using fluorescent dyes. Plant Cell and Environment 17:257-266. https://doi.org/10.1111/j.1365-3040.1994.tb00291.x

Wang H, Wang Z, Wang F, Gu Y, Liu Z (2012). Development of basal endosperm transfer cells in Sorghum bicolor (L.) Moench and its relationship with caryopsis growth. Protoplasma 249(2):309-321. https://doi.org/10.1007/s00709-011-0281-6

Waniska RD (2000). Structure, phenolic compounds, and antifungal proteins of sorghum caryopses. In: Technical and Institutional Options for Sorghum Grain Mold Management: Proceedings of an International Consultation. Patancheru, Andhra Pradesh, India: ICRISAT pp 72-106.

Winston AL (1903). The anatomy of the fruit of certain cultivated sorghums. Connecticut State Agricultural Experiment Station Annual Report 26:326-328. 
Wolswinkel P, Ammerlaan A (1983). Phloem unloading in developing seeds of Vicia fabaL.: the effect of several inhibitors on the release of sucrose and amino acids by the seed coat. Planta 158(3):205-215. https://doi.org/10.1007/BF01075256

Wright KM, Oparka KJ (1996). The fluorescent probe HPTS as a phloem-mobile, symplastic tracer: an evaluation using confocal laser scanning microscopy. Journal of Experimental Biology 47(3):439-446. https://doi.org/10.1093/jxb/47.3.439

Yang, Z, van Oosterom EJ, Jordan DR, Hammer GL (2009). Pre-anthesis ovary development determines genotypic differences in potential kernel weight in sorghum. Journal of Experimental Botany 60(4):1399-1408. https://doi.org/10.1093/jxb/erp019

Zeleznak K, Varriano-Marston A (1982). Pearl millet (Pennisetum americanum (L.) Leeke and sorghum (Sorghum bicolor (L.) Moench) ultrastructure. American Journal of Botany 69(8):1306-1313. https://doi.org/10.1002/j.1537-2197.1982.tb13376.x

OPEN ACCESS

(c) (1)
The journal offers free, immediate, and unrestricted access to peer-reviewed research and scholarly work. Users are allowed to read, download, copy, distribute, print, search, or link to the full texts of the articles, or use them for any other lawful purpose, without asking prior permission from the publisher or the author.

License - Articles published in Notulae Scientia Biologicae are Open-Access, distributed under the terms and conditions of the Creative Commons Attribution (CC BY 4.0) License.

(c) Articles by the authors; SHST, Cluj-Napoca, Romania. The journal allows the author(s) to hold the copyright/to retain publishing rights without restriction. 